\title{
A Tailspin for Taxi Drivers: Platform Labor, Deregulations, and a Migrant Occupation'
}

\section{Helga Hiim Staalhane ${ }^{2}$}

Research Fellow in Sociology, Department of Media and Social Sciences, University of Stavanger, Norway

\section{Anders Vassenden}

Professor of Sociology, Department of Media and Social Sciences, University of Stavanger, Norway

\begin{abstract}
In this article, we investigate Nonwegian taxi drivers' perceptions and experiences of the introduction of Transportation Network Companies (TNCs) such as Uber. We find that taxi drivers are highly critical, but not over technology or TNCs as such. Their critique is directed at government deregulations of the taxi industry, which paved the way forTNC re-entry. Our findings suggest that, if we are to understand how the platform economy changes work-life and its social consequences, we need to comprehend (I) current digital change in its political context, which in our case pertains notably to deregulations. Equally important (2) is that consequences and struggles are seen in light of the history and social trajectory of the specific occupations affected; a central factor in our case being that the taxi industry has become a typical migrant occupation. Our paper contributes to a more comprehensive picture of structural changes in the digital work-life.
\end{abstract}

\section{KEYWORDS}

Deregulations / dual labor markets / immigrant niche / neoliberalism / platform work / taxi industry / Uber

\section{Introduction}

$s$ the platform economy transforms work across the globe, the effects of platform labor, that is, individuals selling their labor on digital platforms, receives increasing attention. In the Nordic context, platform labor is still a marginal phenomenon, but growing within certain segments of the labor market (Illsøe et al. 2020). Some platform companies, such as Uber, have been in the midst of legal battles over the right to operate and have in many places been blocked by national regulations (Oppegaard et al. 2019). In Norway, the main services of TNCs were deemed illegal in 2017 (Oppegaard et al. 2019). However, the deregulation of the taxi industry implemented on October 1, 2020, made a legal comeback of TNCs possible. Uber re-entered Norway three days after deregulations (Giæver \& Solgård 2020).

This article is based on interviews with Oslo taxi drivers in the period where specific deregulations were presented, and shortly before their implementation. We focus on drivers' reactions to the potential re-entrance on TNCs, to industry deregulations, as well as the drivers' predictions for the taxi occupation.

\footnotetext{
${ }^{1}$ You can find this text and its DOI at https://tidsskrift.dk/njwls/index.

${ }^{2}$ Corresponding author: helga.h.stalhane@uis.no.
} 
Our research question is as follows: How do immigrant taxi drivers in Norway perceive changes in their working conditions related to the introduction of TNC's and deregulations, and how does the social and historical context of the taxi industry shape their situation and reactions? We rely on 24 interviews with taxi drivers, and three interviews with industry representatives from the Norwegian Taxi Association and the labor union. The drivers are either permit holders or employed drivers. Permit holders are owner-drivers with one or, in some cases, several cars connected to a dispatch company. The employed drivers are hired by permit holders. More than we anticipated, our data suggest that the recent history and social trajectory of the industry is key to understand how taxi drivers experience both their current labor conditions and how they predict that TNCs and deregulations will influence their occupation.

Furthermore, we argue that the deregulations of the taxi industry, and the initially potential, and subsequently realized, re-entrance of platform labor through TNCs, is a novel phenomenon in a Norwegian context, in that deregulation of an established industry exposes it to platform labor. Main features of these deregulations include removing the number limitation on taxi permits, no longer requiring permit holders to have taxi driving as their primary occupation, and not requiring drivers to be connected to a dispatch company (Aarhaug et al. 2020). In context of the Norwegian labor market, the 'tripartite cooperation' has long roots, where labor unions, employee organizations, and the government attempt to make joint decisions over questions of structure, content, and labor (Hansen et al. 2019). One might have expected this to protect industries from major deregulations. With the taxi industry, both the union and employer organization were against deregulations. Yet, they had minimal influence on the implemented changes. In this connection, we will address in the discussion whether the entrance of TNCs and recent deregulations can be understood as neoliberal policy. This is to consider its wider political ramifications. Potentially, this case could set precedence for other Norwegian industries as well, if deregulations are followed by entrance of platform labor, this despite the wishes of organized workers and employer organizations. In this relation, critical theory of neoliberalism helps us comprehend the resistance found among taxi drivers.

A main contribution of our research is to show how the political context, as well as the history and social trajectory of the specific occupation at hand, is central to understanding the struggles and consequences of platform labor. Through our case study of the Norwegian taxi industry, we position our contribution in relation to two distinct bodies of theory and literature; first, we relate to the sociology of labor, as it connects to technology and deregulations. We argue that the political context of deregulation, which we relate to neoliberal policies, is central to understanding taxi drivers' reactions, as well as the larger political implications this may have for the Norwegian labor market. Second, the article connects to theory on dual labor markets and immigrant niches. The taxi industry is part of a secondary sector, dominated by low income, few benefits, and limited job security. The industry has become an entry into the Norwegian labor market for many migrants, and the occupation has turned into an 'archetypal' migrant occupation. This separates the taxi occupation from most other Norwegian industries, which has possibly made it vulnerable and more easily exposed to platform work. In this article, we will illustrate and discuss this further, and bridge these two bodies of literature.

The article has the following structure. First is a review of current literature, in four parts: platform labor and the taxi industry in the Nordic countries; capitalism

\section{두(1) $\Theta$}


and platform labor; deregulations and its connections to neoliberalism; segmented labor markets and immigrant niches. After next accounting for methodology, we present our findings. Here, we investigate how the drivers perceive the history of the occupation and its former status, and how they regard the occupation today. We also examine their views on TNCs and deregulations, and their outlook on the industry. In our discussion, we analyze TNCs and deregulations from a neoliberal-critic perspective, and then discuss how this interconnects with segmented labor and immigrant niches.

\section{Literature and theoretical framework}

\section{Platform labor in the Nordic Context}

In the Nordic countries, there has been a growing number of empirical studies on platform labor and economy. Illsø, Jesnes, and Hotvedt write that surveys find that less than $2.5 \%$ of the population had done platform work within the last 12 months, but that platform work is growing within parts of the labor market (Illsøe et al. 2020). Further, literature separates between different platform economies, where capital platforms, such as Airbnb, differ from labor platforms such as Uber. People with high income and high education are often on capital platform, where they lease or provide objects they own. Unemployed people, low-skill workers, and migrants are prominent on labor platforms, where they primarily sell their labor (Illsøe \& Larsen 2020). Labor platforms may be a challenge for the Nordic labor models, and Oppegaard writes that platform work has gotten a foothold in areas of labor characterized by low skill- and education requirements, low degree of unionizing, and weak regulations of income and labor conditions, such as in the taxi market and in food delivery (Oppegaard 2020).

Further, the question of employment status is a challenge in platform work, which may have significant consequences for workers right to benefits. Westregård describes how platform companies argue they are simply mediators between customers and workers, hence without employer responsibility (Westregård 2020). For that reason, many platform workers miss out on benefits that typically are provided to employees through collective agreements in Nordic countries (Westregård 2020). Trade unions have continued to criticize platform companies for being unwilling to take on employer responsibility and to provide workers with the security and benefits that follow from employment status, such as unemployment coverage or savings for retirement pension (Illsøe et al. 2020). Furthermore, international research suggests that TNC companies exercise significant control over their workers and the labor they perform through algorithms in the application (Rosenblat 2019), also referred to as algorithmic management (Schildt 2018). 'Algorithm management' entails outsourcing tasks to an external workforce paid per task, who get their bookings and instructions from an algorithm through a mobile app (Schildt 2018). Rosenblat states that by distancing the employer relationship, Uber masks how the power of algorithmic management is actively used to shape and control labor (Rosenblat 2019).

Literature suggests that though challenging, organizing platform workers can improve wages and conditions (Illsøe 2020). Related to this, Jesnes argues that institutional context is important, and that the Norwegian context influences employment strategies. For example, some platform companies develop bybrid models where they 
hire workers on part-time contracts or maintain a somewhat stable relationship with their freelancers over time (Jesnes 2019). An example of this may be food-delivery service Foodora, where workers are organized and on part-time contracts. This in contrast to typical platforms, which see themselves as only an intermediary between customer and the person offering their labor (Jesnes 2019). Uber is an example. In the hybrid model, workers may experience more security regarding payment, health and safety, and quality assurance than what typical platform companies provide. However, Illsøe argues that workers on marginal part-time contracts, such as workers in a hybrid platform model, can still have low annual income and precarious labor (Illsøe 2017). The institutional context is relevant, as pressure from unions and legislators is an important reason why some companies adapt and choose a hybrid model as opposed to the typical platform model (Jensnes 2019). In this connection, it is noteworthy that in the case of the Norwegian taxi occupation, regulations of the taxi industry have been changed and exposed to the TNC labor-model, which is a typical labor platform. This contrasts to having TNCs adjust to Norwegian regulations.

There is limited Norwegian research on TNC work specifically, as Uber X was illegal in Norway until recently. However, a study on Uber Black, Uber's high end limousine service that remained legal in Norway throughout, indicates that challenges may arrive (Oppegaard 2020, 2021). This research shows that drivers experience a high degree of insecurity and external control, imposed on them through Uber's algorithms and the technological work arrangement (Oppegaard 2020, 2021).

\section{Deregulations and the taxi industries in the Nordic countries}

Deregulation of the taxi industry is not unique for Norway, but has been a pattern in all the Nordic countries. Both Finland and Denmark have deregulated the industry in recent years, to varying degrees. The number limitation on taxi permits were lifted in Denmark in 2017, while other requirements, such as taximeter and mandatory seat sensors were kept, restricting Uber's operations in the country (Oppegaard et al. 2019). In Finland, a deregulation act was introduced in 2018, which, like in Denmark, removed the number limitation on permits (Oppegaard et al. 2019). However, in Finland, the deregulation was extensive enough for Uber and other TNCs to legally provide their main services, such as Uber X (Oppegaard et al. 2019). The Nordic anomaly is Sweden, which deregulated the taxi industry as early as 1990 (Oppegaard et al. 2019; Slavnic 2015). Being the first Nordic country to deregulate this industry, Sweden removed the number limitation on permits and no longer required taxis to be connected to dispatch companies (Slavnic 2015). According to Slavnic, deregulation was intended to increase the efficiency and quality of taxi services, and simultaneously secure lower fares (Slavnic 2015). However, results of the deregulation were lower efficiency with fewer rides per taxi, variating prices, more taxation fraud, and decreasing income for drivers (Aarhaug \& Skollerud 2019; Aarhaug et al. 2020; Slavnic 2015). Moreover, an issue arose were taxis without connection to a dispatch would take high prices and provide poor service (Aarhaug $\&$ Skollerud 2019; Slavnic 2015). In 2020, Sweden reintroduced certain regulations, such as requiring drivers to be connected to a dispatch company (Oppegaard et al. 2019).

As discussed in this paper, industry deregulations were implemented in Norway in late 2020, enabling TNCs to re-enter the industry. While these deregulations were 
major to the Norwegian taxi industry, it is important to note that they were not the first deregulations confronting the industry. A partial deregulation was introduced in 1998, allowing more dispatch companies to operate in the same defined permit-areas, like Oslo and surrounding Akershus. This led to the establishment of more and new dispatch companies (Aarhaug et al. 2020). Following the partial deregulations, the maximum price requirement was softened, allowing companies to set their own prates. This led to an increase in prices in the street segment of the market (Aarhaug \& Skollerud 2019).

Furthermore, the Norwegian taxi industry differs from most other work arrangements in Norway. For example, the industry is characterized by low degree of unionizing, common use of commission salary, few regulations of employment conditions, and low pay (Aarhaug et al. 2020). Research has suggested that deregulating the taxi industry may enhance labor problems, in addition to raising other issues regarding organization, taxation, prices, and control in the industry (Aarhaug \& Skollerud 2019). Deregulation in the current form was also cautioned against by many public institutions that were consulted in the matter (Taxiforbundet et al. 2018).

The 2020 deregulations of the Norwegian taxi industry can be understood both as part of a Nordic trend and as an extension of previous deregulation. However, the current deregulations transform the supply side of the industry, as the market opens to an unlimited number of drivers. This, combined with the rise of platform companies, could be a game changer for taxi drivers. As stated, we argue this is novel in a Norwegian context as an existing industry is deregulated enabling the entrance of platform work.

\section{Capitalism in platform work}

Literature focusing on digitalization of work is typically interconnected with discussions of capitalism. A growing body of literature investigates work relations in the platform economy, led by technology companies such as Lyft, Airbnb, Taskrabbit, and Uber (Alsos et al. 2017; Gandini 2018; Purcell \& Brook 2020; Silberman \& Irani 2016; Slee 2017). Critics argue that the digital modes of production that we are entering into are not classical capitalism, but something worse (McKenzie 2014), and that inequality is a feature rather than a bug for workers in platform labor (van Doorn 2017). Digitalization of work in the platform economy can be seen as extending free-market practices into labor areas that used to be protected, squeezing out middle class jobs, and allowing a few people to financially benefit by pushing vulnerable individuals to take work-related risks (Slee 2017; Swick 2018). Swick applies a case study of Uber to show how platform companies applies 'the neoliberal playbook' when they exercise their power to avoid employment responsibility and paying benefits to workers (2018). Others suggest that technology information, though driven by capitalism, has the potential of creating new dynamics undermining economy-based markets and private ownership (Mason 2016). In this relation, literature suggests that the displacement of workers by technology could, under the right circumstances, create more rewarding and safe jobs (Schwab 2016) and that we may imagine worker-owned cooperatives that design their own applicationbased platforms (Scholz 2017). Research and literature foresee different outcomes and futures in the labor-capital relation within technology.

In our research, we find support for the perspective arguing that deregulations connected to capitalistic policy can harm vulnerable workers, and less support of the more 
optimistic perspective of the potential of platform work. More specifically, we argue that the entrance of TNCs and recent deregulation of the Norwegian taxi industry relies on neoliberal policies, and that these deregulations set a novel presence in the Norwegian labor market. Next, we will provide a short introduction of neoliberalism criticism.

\section{Deregulations and neoliberalism}

Neoliberalism springs from capitalism but as an intensified political-economic paradigm (Klein 2007). Critics describe neoliberalism as an ideology or even economic theology about how societies should be managed, presented as a set of rational laws, thus ignoring how it reshapes power relations (Mavelli 2020; Monboit 2016). Monboit describes deregulation as a central feature of neoliberalism, next to privatization, tax cuts, and destruction of trade unions (Monboit 2016). From a neoliberal perspective, the market is self-regulative, requiring little or no intervention from the state (Choi \& Murphy 2001). However, this idea has been heavily criticized. According to Giroux, deregulations and privatization are means for corporations to gain control and dominance in the free market (Giroux 2004). A result is financially polarized societies with deep inequalities between the 'haves' and 'have not's'.

Further, from a neoliberal perspective, the right to sell one's time, labor, etc., is seen as a form of freedom. However, critics argue that this view on freedom does not grasp reality, as selling one's time and labor is a necessity to live, and that neoliberalism relies on a pliable and inexpensive workforce willing to work for low income (Choi \& Murphy 2001). In this sense, the concept of 'freedom of markets' may simply end up being a convenient means to increase corporate power, as suggested by Harvey (2007). Furthermore, Harvey claims that almost all countries have adopted some versions of neoliberal policies (2007). The Nordic welfare states have seen an increase of neoliberal reform and policies implemented in recent years, including in the labor markets (Kamali \& Jonsson 2018). By applying critique of neoliberalism as a theoretical backdrop, we discuss whether and how the entrance of TNCs and deregulation of the Norwegian taxi industry is based on neoliberalism. Furthermore, we suggest that this is a relevant backdrop to gain a broader understanding of driver's resistance towards TNCs and deregulations.

\section{Segmented labor markets and immigrant niches}

To further comprehend and contextualize driver's perception of the occupation and of industry changes, we also apply theory on 'dual' or 'segmented labor markets'. Dual or segmented labor markets refers to labor markets as divided into a primary sector and a secondary sector. The primary sector provides jobs with high pay, solid benefits, opportunities for career development, and job security. The secondary sector represents the opposite, with low income, lack of benefits, insecure jobs, and few or no opportunities for career advancement (Friberg 2012). This is often presented through an hourglass metaphor, where there are jobs at both the top and the bottom, but few jobs requiring intermediate level skills (Berry \& McDaniel 2018). Dual or segmented labor markets are described as creating a demand for migrants who will work low-level jobs, especially as 
they have few options of finding employment at the 'upper level of the hourglass' due to lack of qualifications, limited language skills, or structural discrimination (Friberg 2012; Slavic 2015). Furthermore, literature connects segmented labor markets to neoliberal economies and capital accumulation (Slavic 2015). The vulnerable position of many migrants in the labor market makes this group desirable for employers who hope to fill low-level jobs with few opportunities of advancement with people willing to work for low income (Friberg 2012; Slavic 2015).

Immigrants in Western societies have tended to be concentrated and overrepresented in specific jobs, typically referred to as 'immigrant niches' (Friberg \& Midtbøen 2018). This can refer to jobs that are overrepresented by a variety of immigrants with different countries of origin, or to specific labor markets where a particular group of migrants are clustered (Eckstein \& Giovanni 2018). However, the latter is often referred to as 'ethnic enclaves'. Though not always, immigrant niches are often found in low-income occupations and industries, such as in the cleaning industry or food delivery (Friberg \& Midtbøen 2018). These occupations may be an entryway into employment for migrants. Slavnic argues that the Swedish taxi industry is characterized by ethnic segmentation and challenging working conditions (Slavic 2015). In the same manner, the Oslo taxi industry represents an immigrant niche, which is characterized by low income and long hours (Aarhaug et al. 2020). Although many immigrant niches may be vulnerable to types of deregulations, the extent of deregulations of the Norwegian taxi industry make this case stand out. To properly perceive taxi drivers' reactions to TNCs and deregulations, it is important to understand the occupation as a migrant niche.

\section{Study method and scope}

We base our analyses on a case-study focused on the Oslo taxi industry. The study relies on semi-structured interviews with 20 taxi drivers and three industry representatives. One of these representatives occasionally drives a taxi himself. The representatives are from the Norwegian Taxi Association and the labor union. In addition, we reinterviewed four participants regarding the state of the taxi industry and their work and homelife during Covid-19. In total, then, the study consists of 27 semi-structured interviews, conducted and contained in compliance with guidelines from the Norwegian Center for Research Data. When referring to all interviewees, we describe them as participants. When we do not include industry representatives, we refer to interviewees as drivers.

Interviews were conducted in different locations such as the offices of industry representatives and over Zoom. In addition, a significant number of interviews were conducted at the taxi drivers' waiting lounge at the Oslo airport, which is a cafeteria and gathering place for taxi drivers while waiting to be called for a pickup. Interviews were conducted in the summer and fall of 2019, as well as spring and summer 2020. While a few drivers were introduced through industry representatives, most drivers were approached randomly, mostly at the airport. The interviews varied in length: interviews with drivers typically lasted for about 1 hour, while interviews with industry representatives tended to be longer, closer to 2 hours. Since taxi drivers were interviewed during working hours, they were all compensated for their time and participation in the primary interviews (not when re-interviewed) with a sum of 500 NOK. Since participation in interviews required drivers to take time off from driving passengers, and as this is a 
low-income occupation completely reliant on commission, we believe it fair to compensate drivers for loss of income. Industry representatives received no such compensation.

Reflective of the demographic makeup of the industry, all the drivers interviewed have a migrant background, and they are all men. The majority are from East-Africa (Somalia) and Pakistan, like most taxi drivers in Oslo. However, the study includes a few exceptions, such as participants from India and Afghanistan, in addition to the three industry representatives, who are white non-migrants. The ages of the participants vary from early 20s to participants in their mid-60s. Most of the drivers do not have higher education, with a handful of exceptions.

All interviews were conducted by author 1 , who is a Norwegian born white majority woman in her 30s. Although positionality might have been of relevance as it differs from that of the participants, most interviewees gave the impression of being open and genuine. At no point did any interviewees refuse to answer a question, though they were informed upfront that they were free to do so. Nor did we sense notable hesitancy to our questions. In addition, when drivers were approached randomly, for example, at the airport waiting lounge, most drivers either accepted the request or assisted in finding another driver who would. A likely reason for this is that the interview topics engage most taxi drivers, especially questions of industry deregulation. A limitation of the study is that the interviews are conducted before the latest deregulation were implemented, which means that the drivers had not yet experienced the consequences of these deregulations or platform work. A follow-up study to ours might investigate the long-term effects of deregulations and drivers experiences of it.

In Oslo, the interviews began with questions concerning taxi drivers' current working conditions. We continued by inquiring about changes to come in the industry, focusing on the deregulation of the medallion market and possible entrance of TNCs. We also asked drivers what they believe such changes will mean for them. In addition, the interviewees were asked about their personal history and background, as well as their future hopes and plans (such as hopes for their children's occupations). Interviews were semi-structured, combining a set interview schedule to secure coverage of certain topics in all interviews, with open questions that allowed for elaborate and variating answers, as well as variation in the follow-up questions. For the purpose of this article, all data excerpts from the participants have been translated into English.

This study applies abductive principles (Vassenden 2018). All interviews were transcribed verbatim in NVivo, then systemized by creating categories in a 'grounded' approach. We organized a list of main categories based on central topics that reoccurred in the interviews and that stood out as important to participants' understanding of the topic at hand. Simultaneously, we focused on placing quotations and topics in relation to the research questions (Blaikie \& Priest 2019). We continued by developing numerous subcategories. By applying the functions 'relationships' and 'annotations' in NVivo, we were able to get a clearer picture of how the categories and subcategories related to each other. Furthermore, gaining a better understanding of how the categories were related helped us extract more general themes, such as participants overall experiences or meaning (Morse 2008). In cases where there were variations in perception, we have tried to represent the different voices. Next, we compared our own data to existing research on the taxi and TNC industry, and then mixed our findings with relevant theory that we apply in our analysis. Throughout, we looked for concordance as well as anomalies between data and theory. This led us to some findings that were in line with 
our expectations, while other data were surprising. In the discussion of our findings, we will briefly reflect upon this.

As we now turn to findings, we will start by presenting the occupational history as understood by our participants, which connects to an experiences of status decline. Next, we will discuss their reactions to deregulations, and then their views on technology and TNCs. For the sake of confidentiality, the names of participants that appear in this article have been replaced by pseudonyms.

\section{Findings}

During interviews, it became clear that though a couple of drivers express feelings of ambivalence, most participants are highly critical of the TNC labor model and of deregulations. As one driver plainly says: 'I don't like Uber'. The drivers understand the entrance of TNCs into a deregulated taxi market as harmful to the taxi occupation, which they relate to problems of labor and declining status from the past, and concerns and pessimism about the future of the industry. We start by presenting the history of the occupation as perceived by our participants, because this is relevant to understand their experience of recent industry developments.

\section{Previous status and decline}

Participants who have been drivers for a long period of time or have family members who drove a taxi in the past, suggest that the occupation was once much better situated with higher status. Abdul, who was born in Pakistan, but has lived in Norway since early childhood, is a permit holder in a large dispatch company in Oslo. Through the example of his father, he describes how the 80 s and 90 s were good times to be a taxi driver:

Abdul: (...) because my father drove a taxi at that time, in the 1980s and 1990s. So he had a good job, and at that time it was mostly Norwegians who drove and the occupation had money and respect, both money and respect. (...) he had three cars in Oslo Taxi. Those were the heydays.

Abdul is not the only one who reminisces about a better time in the taxi occupation. This is a sentiment expressed by many drivers, who believe that the occupation once provided both good money and a respectable status. Although humans may tend to idealize the past, the drivers' perception of dwindling status is central to understanding their opposition to TNCs and deregulations. In the drivers' perception of the occupation in the past, lays an acknowledgement that there has since been a declining occupational status. This is explicitly described by many participants, for example, by Pakistani-born permit holder Faisal.

Faisal: No, because the taxi occupation is not what it used to be. There have been large, drastic changes and you cannot compare or measure it to the, the taxi occupation that once was. 
Like Faisal, other drivers describe a fall in occupational status, as well as what they experience as a low occupational status. Runar, who is both a driver and industry representative, expresses it like this:

Runar: (...) there are a lot of drivers who say that if I am going somewhere then I take off my taxi jacket. That is telling, that you don't feel like that status you perhaps should have had, it is not there.

Participants understand the decline in occupational status, and experience of low status, as related to different factors. These factors are often interconnected, and we will describe them in the following.

\section{Factors in occupational status decline}

When asked why they believe there has been a decline in status, some drivers connect it to increased competition and excessive numbers of taxis, also referred to as overestablishment. Participants suggest that over-establishment in the industry contributes to loss of status. They believe too many taxis, compared to customer demand, has led to increased working hours and declining income for each taxi driver, which undermines the occupational status. In this connection, drivers on average report working ten to twelve hours six to seven days a week to make ends meet. Further, some drivers express that over-establishment also leads to cheating and bad behavior amongst certain drivers, caused by the fierce competition to make enough income. Such behavior includes 'stealing' customers, which is when a random taxi picks up a customer that pre-ordered through the dispatch and assigned to another taxi. Another example of bad behavior is when a taxi skips the assigned taxi line and stops to wait for customers directly outside of bars and restaurants, in areas not assigned to taxis, to get to customers first. Some drivers suggest the chase for a living wage incentivizes poor behavior, which deteriorates both the work environment and the reputation of the occupation.

In connection to perceived over-establishment, some participants discuss previous deregulations in the industry. Runar describes how in 1998, the government opened the market for more dispatch companies and more permits, which he believes harmed the industry:

Runar: We have suggested this is a bad model because they did it in Oslo in 1998. At that point we [Oslo Taxi] were the only dispatch, then they opened for more dispatches, more permits because they wanted better quality and lower prices. And then they got, after 20 years they got worse quality and higher prices. And now they want to introduce this in the whole country.

Runar connects previous deregulations to a decline of industry quality and to increased prices. In line with existing research on the Norwegian Taxi industry (Aarhaug \& Skollerud 2019; Aarhaug et al. 2020), Runar explains that several small dispatch companies entered the market with the 1998 deregulations, and that each dispatch company could set their own rates, making the prices unpredictable for customers. He also states that with more permits and cars on the road, more supply but not more demand, small dispatches relying 
on the street segment of the market would jack up the price for each trip to secure income, a point also supported by research (Aarhaug \& Skollerud 2019). Runar believes previous industry deregulations have harmed both the earnings and the reputation of the occupation, which makes him highly critical of further industry deregulations.

Another element that participants perceive as a signal of declining status, is the high volume of foreign-born drivers in the industry. Participants suggest that Norwegianborn drivers have gradually been phasing out of the occupation, while there has been a high volume of foreign-born drivers entering. Hussain, who started to drive in the early 2000s, describes the changes:

Hussain: (...) when I started to drive there were not so many cars on the road, it wasn't so many drivers. And the drivers who were here, generally they were, it was people who had grown up in Norway, to be honest. And even when I get a customer in the car and I start to talk then one of the first things they'll say is: 'wow, you speak good Norwegian'. Then I am surprised because is it that bad?

A similar sentiment is expressed by permit holder Amir. At the airport cafeteria for taxi drivers, he looks around and says:

Amir: $\quad(\ldots)$ when you don't see one ethnic Norwegian around you feel like the status is low.

This connection between recruitment of foreign-born drivers and low social status is highlighted by many participants. Industry representative Olav suggests that no nativeborn Norwegian wants to apply for the occupation because the income is so poor. Others, such as union representative Frank, connects the large number of migrants in the industry to low entry requirements:

Frank: (...) I think this is about them [the government] wanting the threshold to be as low as possible, you know, and they are basically straight out saying that anyone who comes to Norway and who can't find work, well they can drive a taxi. Then the threshold must be as low as possible to create a way in, into salary, into receiving an income. In that sense, it's a disaster for the industry, you know, to just say: 'If you can't do anything else in life you can get a license and then you can drive a taxi'.

Our participants' experience of an occupational status fall connected to an increase of migrant drivers, relates to other research which suggests that a decline in social status and recruitment of migrant workers may be mutually reinforcing (Midtøen \& Friberg 2018).

\section{Deregulations as downward spiral}

Our participants see the central elements of deregulations as very problematic. One reason is that they believe the issue of over-establishment will get worse. Employed driver Omar puts it like this: 
Omar: (...) If there are no limits [to the number of drivers] then there will be very little work, so people will think that there is no point in working if you don't get any customers. So, if there is a bunch of taxi drivers and very few customers, then I think people won't work anymore. Maybe they go back to NAV or they do, find something else. Maybe some will move or something to find a better job somewhere else.

Omar's sentiment is a common one amongst the participants: if an unlimited number of people can register for a taxi permit and drive, then it will be too many drivers, and no one can earn a decent living. As over-establishment is perceived as a challenge before deregulation, it adds fuel to the fire that the government now opens the industry for unlimited numbers. As permit holders no longer need to have taxi as their fulltime occupation, participants fear being replaced by parttime drivers who will use taxis or TNCs as a 'hobby job', as referred to by one driver, to earn a little income on the side. This argument is also supported by research that suggests that digital platforms are typically used as a supplement of income, not a main source (Ilsøe \& Larsen 2020).

Further, some participants suggest that they see clear connections between lower industry requirements and the deregulations. Amongst others, this is suggested by Olav.

Olav: $\quad$ The threshold is very low, and the Minister of Transport and Communications claims that we are going to continue to have high requirements, as it says in the headline of his posts, it's just bullshit. Because he, there are not high requirements at all, you just, you can sign up your private car, you have to sign it into a taxi registry and you get an EU control every year instead of every other year, and then you, you can have a sticker. The rest is up to you.

Again, low industry requirements were perceived as a problem before deregulations. Participants are highly critical of what they understand as lowering the bar even further, potentially harming their industry.

Drivers also fear that the work environment and reputation of the industry will worsen with deregulations, yet another set of issues that is challenging even before deregulation. In this relation, drivers worry that a declining work environment will not only create more arguments between drivers, but also that the status of the occupation will dwindle further if issues such as taxation fraud among drivers becomes an increasing problem, which many participants believe it will. Employed driver Atif thinks this is going to harm the reputation of drivers, and migrant drivers specifically:

Atif: $\quad$ It is very bad because we get a lot of use out of our tax money, and I think people will pay less tax. Then, it is mostly immigrants, it is mostly immigrants in this occupation, I think that hatred is going to affect us immigrants. (...) when people hear it: 'yeah, yeah, it's just immigrants, no wonder'. That's typical language, you know, it is.

From Atif's point, we can see how different negative factors may reinforce each other, which he foresees as being contributed to this being an immigrant niche. From this perspective, deregulations mean a downward spiral for the work environment and reputation of the occupation, as well as for the migrant workers in it. 
Finally, some participants, such as Ashan who has been a permit holder since 1990, explains how the taxi industry never got a proper lift or enhanced status. Instead of improving the occupation, Ashan states that the government is 'squeezing us out' through the deregulations. Many drivers share this concern of being forced out of the industry, and suggest that they have started looking into other employment options. However, their concerns are intensified by the fact that most participants are migrants without higher education - they worry they will not be able to find another job.

\section{Lack of driver perspective - They don't ask us}

As we have shown, our participants are unhappy with deregulations, which they believe will amplify issues in the industry and harm their livelihood. In relation to this, they express feelings of frustration, they suggest the government hardly listens to drivers' perspectives, and that deregulations are made over their heads.

Atif: I think okay, the government has the right to make decisions, but sometimes it's the government's job to ask us as well, what would you like, how do you feel, what can we do, do you have any better suggestions? If we can agree on something together. (...) They can't decide everything themselves, they must ask us in the occupation, that's very important. They ask other things, other workers, but when it comes to us, they won't ask.

For some drivers, the perceived lack of driver perspective in the political decision to deregulate, is connected to a feeling that the government does not care to consider what is going to happen to drivers' income and livelihood. Cismaan, who has been a lease driver for ten years, suggests that drivers are treated as if they were not part of society. In a similar manner, Izam, who holds a permit in a small taxi company, suggests the government gutting the occupation without having any plan to help taxi drivers:

Izam: And he [The Minister of Transport and Communication] has decided this, and a very big, big thing in the occupation. And if he doesn't have any backup solutions or anything, then it will be, it will be about 20000 people who will become poor. (...) So what is he going to do about that, then, or does he have a backup solution for those people? He doesn't have that. He has just decided, so it's decided.

We see how drivers express feeling ignored in the decision-making process intimately connected to their labor, enhancing an experience of dissatisfaction and marginalization.

\section{Openness and curiosity to new technology}

Many drivers urge to point out that the use of technology, in this context the digital tools of TNCs, is not the cause of their critique. In fact, a few participants, such as lease driver Ajaz, praise Ubers digital application: 
Ajaz: $\quad$ So that app. [Oslo Taxis app.] is not, it doesn't have the same quality and abilities that Uber has, I just honestly have to say that. Ubers app. is really good. They are keeping their secret, they're not going to share it [laughs]. Oslo Taxi have a functioning app., they do. It functions, but they are working on it. It has not been long since they launched it.

Ajaz describes the technical aspect of Ubers application as superior to the existing Norwegian taxi applications. He indicates that Oslo Taxi is attempting to follow TNCs technological development. In fact, it appears to be important for several participants to get across that they are not against technological development that they are not 'oldfashioned'. Perhaps this is an important point for drivers to get across as the government states deregulations are introduced to facilitate innovation and the use of new technology (regjeringen 2020), and as politicians and public figures have suggested that industry regulation is preventing the introduction of efficient technology (Blyverket 2019; Brevik 2019).

Ajaz suggests the well-developed technological tools in a regulated market would be welcomed. However, like other participants, he is critical of industry deregulations. In a similar sentiment, Ashan expresses that 'the doors have been open all along' if TNCs would enter the industry under the current regulations and laws (as they were at time of the interviews and before deregulations), but that his problem with TNCs such as Uber is the unregulated model they base their operations on. The same point is expressed by Cismaan:

Cismaan: Uber can come, it doesn't make any difference. I have nothing against that as long as the rules that have been in Norway [are followed], then it would have been much better. (...) that they must pay the same as we pay, goods and service fees, employer fees, tax, those things.

Participants' discussion of introducing new technological tools, even TNC applications, in the Norwegian taxi market is noteworthy. Participants' main concern lays with allowing TNCs without the current industry- and labor regulations, which is not a matter of technology skepticism. They are primarily upset that the Norwegian government is changing the regulations of their industry, which they believe will deteriorate their labor conditions.

\section{Worries attached to TNCs}

As mentioned, our participants' critique of TNCs is not focused towards technology, but the platform labor model TNC work builds on. What then, is their critique of this labor model and how does it connect to deregulations?

A central concern for taxi drivers regarding TNCs is that the wage will be too low. They suggest TNC's main advantage is underpricing, not technologic superiority, and that TNC-work would not provide them with fulltime work and a living wage. Olav is concerned with what he perceives as underpricing, and he suggests low prices in TNCs makes the drivers pay equally low. A similar concern is expressed by Hussain: 
Hussain: (...) if you are taking 40-50 kroner per trip. (...) okay, it is cheap, you will be preferred [by customers] but this is not a big enough market for you to survive on 40, 40 kroners. You won't get that many trips in Oslo, not enough to make that work.

Participants suggest that as a TNC driver you might get more trips as the customer will prefer the service that charges less. However, with an unlimited number of potential drivers, as suggested through deregulations, they believe there will not be enough trips for each driver to make this an occupation with a living wage.

Another concern for drivers is what they perceive as lack of labor rights in the TNC labor model. One issue described is deactivation. Deactivation, as discussed in other literature, is basically a technology term for being temporarily or permanently fired (Rosenblat 2019). Omar relates this to uneven power relations, placing the drivers on one side and TNCs and customers on the other:

Omar: (...) sometimes they don't listen to the driver, they listen to the customer. If the customer complains, maybe the customers lie, then they close the app from you like that, and then you can't work for three, four days. You don't earn money. (...) That happened to my friend in England.

Omar fears that TNCs will always favor of the customers and deactivate drivers without warning or process, a practice that is documented in other countries (Rosenblat 2019). In a related manner, some participants express skepticism towards the TNCs rating system, where drivers are relying on constant good ratings to avoid deactivation. Runar explains that in the Oslo Taxi application, there is no rating system or identification of the drivers' face to the customers before pickup, because they do not like that concept. Related to this, research from the U.S. shows that drivers get deactivated if their rating falls under four stars - five being the top rating (Rosenblat 2019).

Furthermore, a few drivers discuss the lack of benefits as a problem with TNCs. Cismaan fears he will lose his benefits under Uber's platform labor model:

Cismaan: Today, Uber takes 25 percent. You don't have any rights, a person doesn't have any rights, no vacation money, no sick leave, no unemployment benefits.

As discussed by other literature, platform companies typically consider workers to be independent contractors, and TNC drivers are not entitled to the same benefits as employees (Illsøe et al. 2020; Westergård 2020). At the time of the interviews, the drivers have not experienced working for TNC companies and are uncertain of how this will unfold. Although the issue of lacking benefits for TNC workers is brought up by a few participants, it is interesting that not more drivers discuss this topic. This could possibly indicate that not all drivers are aware of the extent of this issue, which may prevent efficient resistance towards the implementation of such schemes.

\section{Discussion and conclusion}

Norwegian taxi drivers' resistance towards TNCs is mostly based on a rejection of industry deregulations, and they have interconnected reasons to be critical of these 
deregulations. Considering the context of this specific occupation, we find that issues that have been growing in the occupation over the last few decades are perceived as amplified through both previous and most recent deregulations. In addition, the political context in which platform labor is introduced is important. The deregulation of an established industry followed by platform work, differ from how other platforms have entered Norway. This process has provoked many drivers and risen concerns over the future and livelihood of their occupation. Furthermore, the status decline and deregulation of the taxi occupation connects to the taxi industry being an immigrant niche. We will now discuss this.

First, the entrance of TNCs following the deregulation of the Norwegian taxi industry represents something new in Norwegian context. From one perspective, deregulations can be understood as an acknowledgment by the Norwegian government that TNCs are part of the taxi industry, and that TNCs cannot operate with different regulations than taxis. This is not a given, as TNCs have been allowed to operate with different requirements and less regulations than taxis in some cities in the world (Esbenshade \& Shifrin 2019). However, the deregulation of the taxi industry has enhanced the immediate level of conflict, as taxi drivers believe the TNC labor model will diminish their work. Some participants imagine and accept the entrance of TNCs into a regulated Norwegian taxi market. This is mainly because they do not oppose certain aspects of TNCs digital tools if the labor conditions and competition was regulated. However, the opposite has happened, as the taxi industry was deregulated and then exposed to the platform labor model. From a critical perspective, this can be understood as a victory of neoliberal politics, where free market policies, encouraged by the corporate interests of TNCs, has steered the development and regulations of Norwegian labor and work relations. The free market policies that these industry changes represent directly oppose taxi drivers' own wishes and desires for the industry. This is central to their expressions of resistance, as well as to their experience of being ignored in the process.

To our participants, a main worry regarding working conditions is that the income of their occupation will decline. This worry is not unfounded, as research from the U.S. and Canada describes a decline in income for all drivers, taxies and TNC drivers alike, in the cities where TNCs are at the most evolved stage (Rosenblat 2018). However, this needs to be investigated over an extended period, as TNCs lower drivers' income over time (Rosenblat 2018). If we see similar patterns in Norway, taxi drivers have good reason to be concerned by the future livelihood of their occupation. This also aligns with criticism of neoliberalism, where theorists foresee increased financial polarization in society caused by deregulations and the advancement of corporate power (Giroux 2004; Monboit 2016). Drivers foresee themselves having declining income, limited opportunities of other employment, and becoming the 'have nots' in society. In this sense, they experience being marginalized.

In connection to over-establishment, it is relevant to point out that a main pillar for TNCs is to have the potential of an unlimited number of drivers that can be easily mobilized, the same aspect that drivers foresee harming their income. Again, this illustrates how the establishment of TNCs in Norway resembles introduction of a neoliberal labor model. In neoliberal tradition, these companies rely on easy access to inexpensive and pliable workers, much contrary to what is standard employment in Norway. For TNCs to have easy access to a large pool of drivers, it is also in these companies' 
interest to have a low threshold into the industry, an interest our participants believe is realized through deregulations. In this relation, deregulations may become a way for corporations such as Uber to spread their labor model and secure corporate interest, quite like neoliberal-critics explain (Harvey 2007; Mavelli 2019). The implementation of deregulations pays little attention to the well-being and rights of both taxi and TNC drivers, which is the crux of the matter for our participants, and crucial to their resistance towards deregulations.

Furthermore, we may ask if the case of the taxi industry will set precedence in the Norwegian context. In this connection, we need to understand the position of the taxi industry before deregulations. Participants describe a situation where the occupation has undergone a status decline over a longer period, related to previous deregulations and status decline, combined with the phase out of native-born drivers. When we place the taxi industry in the context of being an immigrant niche and as a part of the secondary labor market, it illustrates how the taxi occupation has become peripheral. This made the industry vulnerable to these changes, and as we show in our findings, taxi drivers experience being powerless and marginalized in the process of deregulations. The industry organizations have had little impact resisting these political changes, and the industry and its workers were not able to withstand precarization. Although this case of platform labor may well set precedence in Norway, we cannot assume that it automatically transfers to other industries that are not immigrant niches in the secondary labor market, as industries in the primary labor market have a more robust starting point and may be better positioned to reject such changes. As platform work grows, its connections to migration and immigrant niches should be investigated in other industries as well.

Furthermore, all the negative factors that participants describe are interconnected. Elements such as low wages, low entry requirements, and high job insecurity are typical for migrant niches, and the decline of social status and increase of migrant workers tend to be mutually reinforcing (Friberg \& Midtbøen 2018). These are all factors that characterized the taxi industry before the latest deregulations. However, instead of seeing an improvement of labor conditions for the workers in an immigrant niche, the drivers are experiencing that their work content and labor rights are worsened through deregulations and that they are squeezed out of the industry - and potentially the labor market altogether. In reliance with other literature on platform labor, the process of deregulations and re-entrance of TNCs can be understood as an entrance of neoliberal and freemarket policies into a labor arena and an industry that were still somewhat protected. In this regard, the recent changes in the taxi industry have further immobilized a vulnerable group of migrant workers.

\section{References}

Aarhaug, J. and K. H. Skollerud (2019). "Drosjeregulering i norske byer - utfordringer og alternativer" [Taxi regulations in Norwegian cities - challenges and alternatives]. TØI report 1698/2019.

Aarhaug, J., Oppegaard, S. M. N., Gundersen, F., Hartveit, K. J. L., Skollerud, K. H. and Dapi, B. (2020). "Drosjer i Norge fram mot 2020" [Taxis in Norway towards 2020]. TØI report 1802/2020. Fafo report 2020:24. 
Alsos, K., Jesnes, K., Øistad, S. B. and Nesheim, T. (2017). “Når sjefen er en app” [When the boss is an app]. Fafo report 2017:41.

Berry, C. P. and McDaniel, S. (2018). "Young Workers and Trade Unionism in the Hourglass Economy”. Sheffield Political Economy Research Institute (SPERI) Report. Publisher: Unions 21 in conjunction with Slater and Gordon.

Blaikie, N. and Priest, J. (2019). "Designing Social Research” (3.edt.) Policy Press, Cambridge.

Blyverket, L. I. (2019). "Nye regler for ei ny tid" [New rules for a new time] Dagbladet, June $17,2019$.

Breivik, A. (2019). "Deregulerer taxinæringen” [Deregulating the taxi industry] Dagbladet, December 12, 2019.

Choi, J. M. and Murphy, J. (2001). “A Postmodern Critique of Neo-Liberalism” "Postmodern Productions”, Eds. Nonhoff, M. Bunzmann, K. and Angermuller, J. New Brunswick: Transaction Publisher, pp. 63-73.

Eckstein, S. and Peri, G. (2018). "Immigrant niches and immigrant networks in the US labor market” RSF: “The Russell Sage Foundation Journal of the Social Sciences” 4(1): 1-17.

Esbenshade, J. and Shifrin, E. (2019). "The leased among us: Precarious work, local regulation, and the taxi industry" "Labor Studies Journal" 44(3): 193-213. DOI: https://doi. org $/ 10.1177 / 0160449 X 18768047$.

Friberg, J. H. (2012). "Culture at work: Polish migrants in the ethnic division of labour on Norwegian construction sites" "Ethnic and Racial Studies" 35(11): 1914-1933. DOI: https://doi.org/10.1080/01419870.2011.605456.

Friberg, J. H. and Midtbøen, A. H. (2018). "Ethnicity as skill: immigrant employment hierarchies in Norwegian low-wage labour markets" "Journal of Ethnic and Migration Studies" 44(9): 1463-1478. DOI: https://doi.org/10.1080/1369183X.2017.1388160.

Friberg, J. H. and Midtbøen, A. H. (2019). "The Making of Immigrant Niches in an Affluent Welfare State" “International Migration Review” 53(2): 322-345. DOI: https://doi. org/10.1177/0197918318765168.

Gandini, A. (2019). "Labour process theory and the gig economy" "Human Relations" 72(6): 1039-1056. DOI: https://doi.org/10.1177/0018726718790002.

Giroux, H. A. (2004). “The Terror of Neoliberalism” London: Paradigm Publishers.

Giæver, H. and Solgård, J. (2020). "Den omstridte drosjetjenesten Uber gjør comeback i Norge" [The controversial taxi service Uber makes a comeback in Norway]. Dagens Næringsliv, October 27, 2020.

Hansen, K., Haaland, G. and Vagle, I. (2019). “Makt og innflytelse i prosessen med å endre strukturen i yrkesopplæringen" [Power and influence in the process of changing the structure in vocational training]. "Scandinavian Journal of Vocations" 4(1): 136-173.

Harvey, D. (2007). “A Brief history of Neoliberalism.” Oxford: Oxford University Press.

Ilsøe, A. (2020). "The Hilfr agreement: Negotiating the platform economy in Denmark". Report from: Employment Relations Research Centre Department of Sociology University of Copenhagen.

Ilsøe, A., Jesnes, K. \& Hotvedt, M. (2020). "Social partner responses in the Nordic platform economy" "Platform work in the Nordic models", Eds. K. Jesnes, \& S. Oppegaard. Nordic Council of Ministers. TemaNord, 2020(513): 68-78.

Ilsøe, A. and Larsen, T. P. (2020). "Digital platforms at work. Champagne or cocktail of risks?" "The Impact of the Sharing Economy on Business and Society: Digital Transformation and the Rise of Platform Businesses” Eds. A. Strømmen-Bakhtiar, E. Vinogradov. Routledge, pp. 1-20. DOI: https://doi.org/10.4324/9780429293207.

Ilsøe, A., Larsen, T. P. and Felbo-Kolding, J. (2017). "Living hours under pressure: flexibility loopholes in the Danish IR-model" "Employee Relations" 39(6): 888-902. DOI: https:// doi.org/10.1108/ER-03-2017-0049. 
Irani, L., \& Silberman, M. (2016). "Stories We Tell About Labor: Turkopticon and the Trouble with Design" Proceedings of the 2016 CHI Conference on Human Factors in Computing Systems. San Jose California USA: ACM, pp. 4573-4588. DOI: https://doi. org/10.1145/2858036.2858592.

Jesnes, K. (2019). "Employment Models of Platform Companies in Norway: A Distinctive Approach?" "Nordic Journal of Working Life Studies” 9(Special issue no. S6): 53-73. DOI: https://doi.org/10.18291/njwls.v9iS6.114691.

Jesnes, K. and Oppegaard, S. M. N. (2020). "Platform work in the Nordic models: Issues, cases and responses." Report from: The Future of Work: Opportunities and challenges for the Nordic models, Oslo: Nordic council of ministers; 2020.

Klein, N. (2007). “The Shock Doctrine, The Rise of Disaster Capitalism.” New York: Picador.

Mason, P. (2016). "Postcapitalism: A guide to our future Macmillan." London: Penguin Books.

Masoud, K. and Jönsson, J. H. (2018). Preference in "Neoliberalism, Nordic welfare states and social work: Current and future challenges." Oxfordshire: Routledge.

Mavelli, L. (2020). "Neoliberalism as Religion: Sacralization of the Market and Post-truth Politics," “International Political Sociology" 14(1): 57-76. DOI: https://doi.org/10.1093/ ips/olz021.

McKenzie, W. (2014). "Digital Labor and the Anthropocene” DIS Magazine, November 29, 2014.

Monbiou, G. (2016). "Neoliberalism - the ideology at the root of all our problems". The Guardian, April 15, 2016.

Morse, J. M. (2008). "Confusing Categories and Themes" "Qualitative Health Research" 18(6): 727-728. DOI: https://doi.org/10.1177/1049732308314930.

Mydske, P. K., Claes, D. H. and Lie, A. (2007). "Nyliberalisme - ideer og politisk virkelighet.” Oslo: Universitetsforlaget.

Norges taxiforbund, OsloTaxi, Bytaxi and Christiania taxi (2018). Report: "Systematisering av høringssvarene til Samferdselsdepartementets forslag til endringer i drosjereguleringen" [A systematization of the consultation statements regarding the Ministry of Transport's suggestion to change the taxi regulations].

Oppegaard, S. M. N., Ilsøe, A., Jesnes, K., Rolandsson, B. and Saloniemi, A. (2019). "Uber in the Nordic countries: Challenges and adjustments." Nordic future of work Brief 1.

Oppegaard, S. M. N. "Gig- Og Plattformøkonomien i Den Norske Arbeidslivsmodellen Forutsetninger Og Konsekvenser. En Casestudie Av Uber Black i Oslo.” [The gig- and platform economy in the Norwegian working life model - preconditions and consequences. A case study of Uber Black in Oslo] "Norwegian Journal of Working Life Studies" 37(3): 168-182. DOI: https://doi.org/10.18261/issn.1504-7989-2020-03-03.

Oppegaard, S. N. M. (2021). "Regulating Flexibility: Uber's Platform as a Technological Work Arrangement," "Nordic Journal of Working Life Studies" 11(1): 109-127. DOI: https://doi.org/10.18291/njwls.122197.

Purcell, C. and Brook, P. (2020). “At Least I'm My Own Boss! Explaining Consent, Coercion and Resistance in Platform Work" "Work, Employment and Society", 00(0): 1-16. DOI: https://doi.org/10.1177/0950017020952661.

Regjeringen.no. (2020). “Spørsmål og svar om nytt drosjeregelverk” [Questions and answers about the new taxi regulations]. August 14, 2020.

Rosenblat, A. (2019). "Uberland: how algorithms are rewriting the rules of work" Oakland, California: University of California Press.

Rosenblat, A. (2018). "Uber shows us that technology is political - not neutral" The Globe and Mail, November 9, 2018.

Scholz, T. (2017). "Platform Cooperativism vs. the Sharing Economy". "Big Data \& Civic Engagement” ed. Douay, N. and Wan, A. Milan: Planum publisher, pp. 47-54. 
Schwab, K. (2016). “The Fourth Industrial Revolution” World Economic Forum, January 14, 2016.

Schildt, H. (2018). "Servants: Algorithmic management of work". Unpublished, working draft. Helsinki: Aalto School of Business.

Slavic, Z. (2015) "Taxi drivers: ethnic segmentation, precarious work, and informal economic strategies in the Swedish taxi industry," "Journal of Business Anthropology" 4(2): 298-319. DOI: https://doi.org/10.22439/iba.v4i2.4894.

Slee, T. (2017). "What's Yours Is Mine: Against the Sharing Economy.” New York: OR Books.

Swick, A. (2018). "Welcome to the Gig Economy: neoliberal industrial relations and the case of Uber," “GeoJournal” 83(4): 679-691. DOI: https://doi.org/10.1007/s10708-0179793-8.

Van Doorn, N. (2017). "Platform labor: on the gendered and racialized exploitation of low-income service work in the 'on-demand' economy" "Communication, Information \& Society” 20(6): 898-914. DOI: https://doi.org/10.1080/1369118X.2017.1294194.

Vassenden, A. (2018). "Productive Anomalies. Theory Development in Empirical Sociology," "Norwegian Journal of Sociology" 2(2): 145-163. DOI: https://doi.org/10.18261/issn. 2535-2512-2018-02-03.

Westregård, A. (2020). "Digital collaborative platforms: A challenge for both the legislator and the social partners in the Nordic model." "European Labour Law Journal" 11(2): 142-153. DOI: https://doi.org/10.1177/2031952520905154 